\title{
DNA promoter methylation as a diagnostic and therapeutic biomarker in gallbladder cancer
}

\author{
Pablo Letelier ${ }^{1}$, Priscilla Brebi ${ }^{1}$, Oscar Tapia ${ }^{1,3}$ and Juan Carlos Roa ${ }^{1,2,4^{*}}$
}

\begin{abstract}
Gallbladder cancer is an infrequent neoplasia with noticeable geographical variations in its incidence around the world. In Chile, it is the main cause of death owing to cancer in women over 40 years old, with mortality rates up to 16.5 per 100,000 cases. The prognosis is poor with few therapeutic options; in advanced cases there is only a $10 \%$ survival at 5 years.

Several studies mention the possible role of DNA methylation in gallbladder carcinogenesis. This epigenetic modification affects tumor suppressor genes involved in regulation pathways, cell cycle control, cell adhesion and extracellular matrix degradation, in a sequential and cumulative way. Determining DNA methylation patterns would allow them to be used as biomarkers for the early detection, diagnosis, prognosis and/or therapeutic selection in gallbladder cancer.
\end{abstract}

Keywords: Epigenetics, Gallbladder cancer, Methylation, Tumor suppressor gene

\section{Review}

\section{Gallbladder cancer}

Gallbladder cancer $(\mathrm{GBC})$ is the most frequent malignant tumor of the biliary tract and the fifth most common cancer of the digestive tract. The presenting symptoms are vague, so diagnosis commonly occurs at an advanced stage. This late diagnosis combined with the fact that the gallbladder lacks a serosa result in a rather dismal prognosis [1-3]. The highest GBC incidence rates have been reported in women from India (21.5 out of 100,000), Chile (18.1 out of 100,000), Pakistan (13.8 out of 100,000) and Ecuador (12.9 out of 100,000). High incidences have also been found in Korea and Japan and some central and eastern European countries such as Poland, the Czech Republic and Slovakia [4]. These facts suggest significant genetic-environmental influences in the development of the disease [5].

Several factors have been associated with the risk of developing GBC. Lithiasis is one of the main risk factors, presenting in $65 \%$ to $90 \%$ of cases of GBC [2,3,6,7]; the risk is also associated with the number and size of the

\footnotetext{
* Correspondence: jcroa@ufro.cl

'Universidad de La Frontera, School of Medicine, Department of Pathology, Molecular Pathology Laboratory, BIOREN-CEGIN, Temuco, Chile

${ }^{2}$ Pontificia Universidad Católica de Chile, School of Medicine, Department of Pathology, Santiago, Chile

Full list of author information is available at the end of the article
}

stones [8]. Likewise, and closely connected with lithiasis, chronic gallbladder inflammation might induce the continuous release of inflammatory mediators and growth factors (tumor promoters), which exert their effect on an epithelium previously damaged by carcinogenic agents [9]. Gallbladder cancer has also been associated with multiple familial polyposis (Gardner syndrome), PeutzJeghers syndrome, 'porcelain' gallbladder and anomalous pancreatobiliary ductal union [7].

Adenocarcinoma is the most frequent histological type found in GBC. It represents $80 \%$ to $95 \%$ of all tumors, and the most frequent forms are moderately or poorly differentiated [1,2]. Two carcinogenic models of GBC sequence are recognized: the metaplasia-dysplasiacarcinoma and the adenoma-carcinoma, which have origins in two different types of epithelial lesion in the gallbladder. The metaplasia-dysplasia-carcinoma sequence, the most significant and frequent type of gallbladder carcinogenesis, is based on alterations to the epithelium of the gallbladder mucosa. The metaplasia frequently appears as an adaptive process secondary to chronic irritation or inflammation. Dysplasia appears on top of this metaplasia, which progresses to carcinoma in situ and subsequently becomes invasive (Figure 1). Severe dysplasia and carcinoma in situ have been found in more than $90 \%$ of GBC [10-12]. Less frequent is the second pathway (adenoma- 


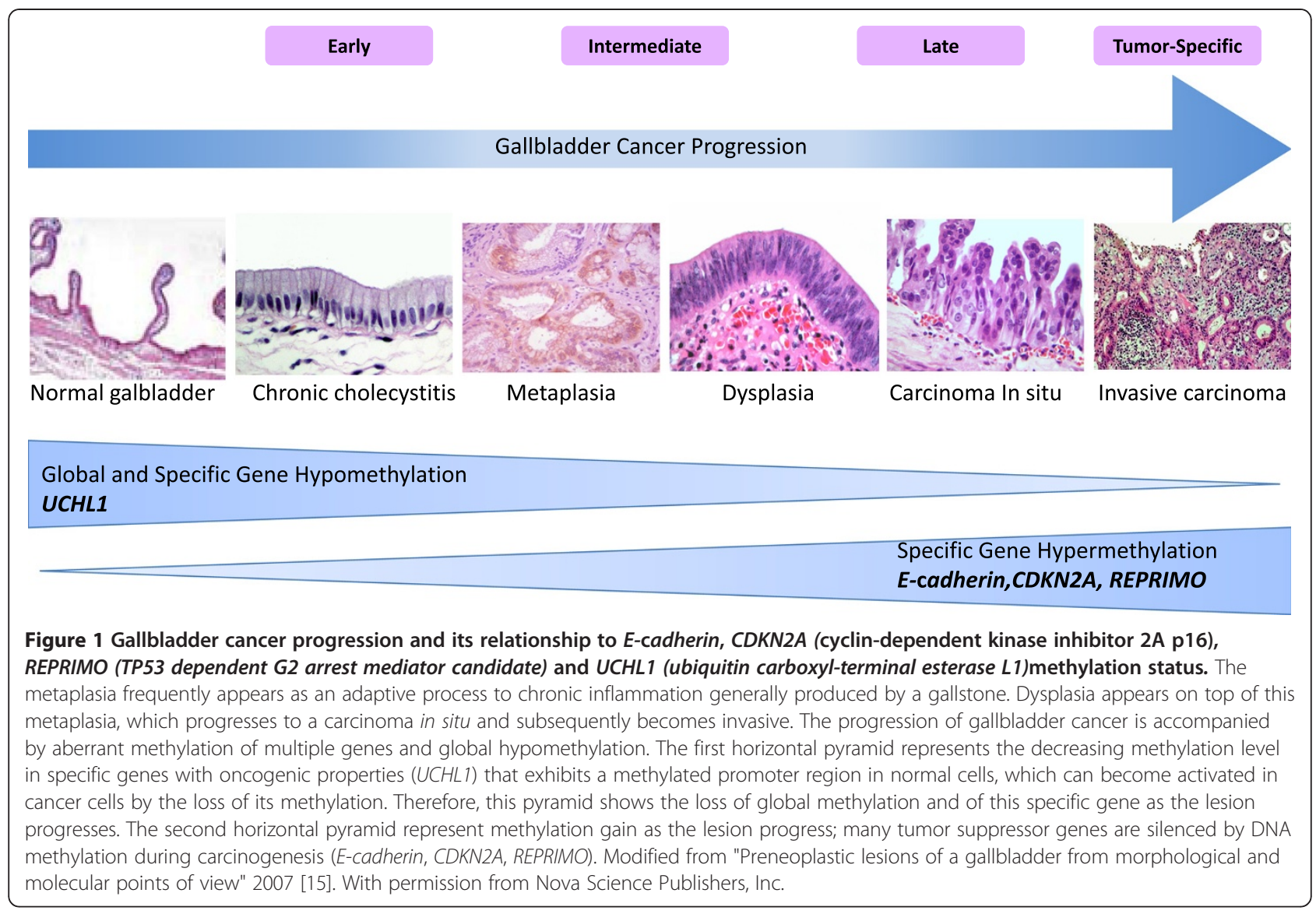

carcinoma sequence), which suggests a malignant transformation from an adenomatous lesion [10,13]. The clinical and experimental evidence supports both models, and genetic-molecular studies show that the two pathways are distinct biological events $[10,12,14]$.

Gallbladder carcinogenesis has been demonstrated to be a multifactorial process that involves genetic and ambient factors. For innovating early diagnosis, biomarkers and new therapeutic strategies, it is necessary to explore the molecular mechanisms of GBC development and progression, among them, epigenetic modifications.

\section{Epigenetics}

Epigenetics is currently understood and defined as the inheritance of gene expression patterns not determined by the nucleotide sequence [16]. Alterations in the established epigenetic patterns generally lead to changes in gene expression, which can cause transcriptional repression [17]. The classic epigenetic modifications include DNA methylation, histone modification (acetylation, methylation, phosphorylation, and so on) and chromatin remodeling. A few years ago, a new epigenetic phenomenon was discovered, RNA interference, that has been shown to be involved in post-transcriptional silencing [18].
The most frequently studied epigenetic mechanism is DNA methylation, involved in the control of various biological processes in prokaryotes and eukaryote cells. In mammalian cells, DNA methylation only takes place at position $5^{\prime}$ of the cytosine ring in cytosine-guanine dinucleotides $(\mathrm{CpG})$ through the covalent bond of a methyl group $[17,19]$. Non-CpG sequences can also by methylated but with less frequency [20]. Generally, the CpG dinucleotide is poorly represented in the human genome, being approximately $1 \%$ of all nucleotide bases. The majority of these dinucleotides are dispersed throughout the genome in retrotransposon sequences and coding and non-coding gene regions. A lower percentage of $\mathrm{CpG}$, little more than $15 \%$ of the total, is located in regions called $\mathrm{CpG}$ islets [21]. In approximately $60 \%$ of human genes, the $\mathrm{CpG}$ islets reside in promoters, first exons and $5^{\prime}$ untranslated region (5'UTRs) [22]. In normal cells, most dinucleotides located in repetitive regions of the genome (satellite DNA and endoparasitic elements) outside of CpG islets are methylated [23]. By contrast, the $\mathrm{CpG}$ islets are generally not methylated, except those located in the inactive chromosome $\mathrm{X}$, in imprinted genes, specific germ-line genes, and in tissuespecific genes [24]. In normal tissue, methylation of some CpG islets usually increases with age, although the total 
genomic content of the methylcytosines decreases [25]. These same events are present in tumor cells, but are much more pronounced. The loss of methylation occurs in normally methylated CpG sites (in repetitive and/or endoparasitic sequences) and is known as overall genomic hypomethylation. The second alteration, characterized by an increase of methylation in $\mathrm{CpG}$ islets in normally demethylated regulatory regions, is known as aberrant hypermethylation. Many tumor suppressor genes are silenced by DNA methylation during carcinogenesis [26].

Genes that show oncogenic properties, that is, that exhibit a methylated promoter region in normal cells, can become reactivated in cancer cells by the loss of this methylation, resulting in hypomethylation [27]. In general, the chromosomal instability, loss of imprint, reactivation of transposable elements and transcriptional silencing of tumor suppressor genes or oncogene activation are of great benefit to the tumor cell [26].

\section{Methylation studies on the gallbladder Aberrant methylation in preneoplastic gallbladder lesions} Chronic cholecystitis is an inflammatory disease associated with the presence of gallstones, which predetermines the appearance of the first morphological changes described in the metaplasia-dysplasia-carcinoma cancer sequence. House et al. [28] evaluated the hypermethylated state of six tumor-associated genes in a normal gallbladder, chronic cholecystitis and adenocarcinomas (samples fixed in formalin and embedded in paraffin) in a series of Chilean patients. In patients with chronic cholecystitis, they reported $28 \%$ methylation in some of the genes $(A P C, p 16$ and $h M L H 1)$, whereas only one case (5\%) presented multigene methylation [28]. Likewise, García et al. [29] determined the gene methylation pattern in preneoplastic and neoplastic gallbladder lesions, finding that $D A P K-1, D L C-1, T I M P-3$ and $R A R \beta-2$ presented a progressive increase in their state of methylation from chronic cholecystitis to advanced carcinomas [29], reporting at the same time an aberrant methylation pattern of the gene for E-cadherin ( $C D H 1)$ with a progressive increase in the methylation from chronic cholecystitis without metaplasia to advanced carcinoma (53\% to 65.2\%) [29]. Recently Shin et al. [30] reported that genes TWIST1, HOXA1, SFRP1, PENK, GRIN2B, CDH13, NEUROG1, TMEFF2, TIMP3, MINT2, CCND2, RASSF1A, RUNX3, DLC1, CRABP1, GATA3, MT1G, SEZ6L, SOCS3, THBS1 and BCL2 were significantly methylated in extrahepatic cholangiocarcinoma (EHC) tissue samples, at higher levels than in cholecystitis and cholangitis tissues. This analysis was able to define a five-gene panel (CCND2, CDH13, GRIN2B, RUNX3 and TWIST1) in bile fluid samples capable of detecting EHC at a sensitivity of $83 \%$, which was far higher than that of bile cytology $(46 \%, P<0.05)$ [30].

\section{Aberrant methylation in gallbladder cancer}

The methylation information available in cancers of the biliary tract is limited compared with other neoplasms. Nevertheless, studies have established that aberrant hypermethylation is an important event in the carcinogenesis of GBC (Table 1) [31-38]. Published studies have made it possible to establish that transcriptional gene silencing is due to the methylation state of its promoter regions, a mechanism that is alternative to mutation and allelic deletions. This seems to be an early, progressive and cumulative event in GBC, which increases from chronic cholecystitis without metaplasia to metaplasia. The variation of methylation frequencies in cases of different geographical origin, which suggests population differences, is worthy of note, because similar results have been observed in a study of genetic alterations (mainly mutations) [28]. For example, Takahashi et al. [32] reported in 2004 that, in Chilean patients, SHP1 (80\%), 3-OST-2 (72\%), CDH13 (44\%), P15INK4B (44\%), CDH1 (38\%), RUNX3 (32\%), APC (30\%), RIZ1 (26\%), P16INK4A (24\%) and HPP1 (20\%) presented a high percentage of methylation in patients with GBC (Table 1) [32]. For their part, García et al. [29] assessed the methylation state in CDH13 (69.6\%), DAPK1 (60.9\%), FHIT (56.5\%) and RAR beta 2 (43.5\%), genes which presented a high methylation frequency in advanced GBC in Chilean patients (Table 1). In addition, both of them found that the methylation state of $D L C 1$ was an indicator of poor prognosis, and methylation of $M G M T$ is correlated with better survival [29]. Other authors evaluated the methylation states of $A P C$ and FHIT and their relationship to survival, with methylation percentages of $40 \%$ and $30 \%$, respectively. No correlation was found between survival and methylation state [39]. Epigenetic inactivation by methylation in chromosome $3 \mathrm{p}$ is a frequent event in patients with GBC, particularly affecting the promoter region of the tumor suppressor genes SEMA3B (3p21.3) and FHIT (3p14.2) with 92\% and 66\% methylation, respectively [40]. RASSF1A inhibits the expression of the RAS oncogene, acting as a tumor suppressor gene through different pathways, including apoptosis, genomic stability and cell cycle regulation [41]. Epigenetic silencing in this gene has been reported in different human tumors, such as in lung, breast, brain, prostate, pancreas and kidney cancers [41]. In the gallbladder, it was found that the methylation in exon 1 of this gene was $36.4 \%$ in carcinoma samples, $25.0 \%$ in adenoma and $8.0 \%$ in normal epithelium $[42,43]$. When RASSF1A methylation was correlated with immunohistochemical expression, weak or no staining of the tumor cells was observed. The methylation frequency of this gene in cholangiocarcinoma can reach $65 \%$, which, despite the close anatomical relationship with GBC, has different methylation patterns $[44,45]$. We also observed 
Table 1 Summary of the methylation rate of multiple genes studied in advanced gallbladder cancer

\begin{tabular}{|c|c|c|c|c|c|c|}
\hline Gene name & Full name & Function & $\begin{array}{l}\text { Frequency of } \\
\text { methylation \% (n) }\end{array}$ & $\begin{array}{l}\text { Origin of } \\
\text { specimen }\end{array}$ & Method & Reference \\
\hline \multirow[t]{6}{*}{$\overline{C D H 1}$} & \multirow{6}{*}{$\begin{array}{l}\text { Cadherin 1, type 1, } \\
\text { E-cadherin (epithelial) }\end{array}$} & \multirow{6}{*}{$\begin{array}{l}\text { Tissue invasion } \\
\text { (cell-cell adhesion) }\end{array}$} & $11(1 / 9)$ & Japan & MSP & Tozawa et al. 2004 [43] \\
\hline & & & $38(19 / 50)$ & Chile & MSP & Takahashi et al. 2004 [32] \\
\hline & & & $65(13 / 20)$ & Chile & MSP & Roa et al. 2006 [39] \\
\hline & & & $60(13 / 20)$ & Chile & MSP & Roa et al. 2008 [46] \\
\hline & & & $65(15 / 23)$ & Chile & MSP & García et al. 2009 [29] \\
\hline & & & $41(9 / 22)$ & Japan & $\begin{array}{l}\text { Nested } \\
\text { MSP }\end{array}$ & Koga et al. 2005 [47] \\
\hline \multirow[t]{4}{*}{ FHIT } & \multirow[t]{4}{*}{ Fragile histidine triad gene } & \multirow{4}{*}{$\begin{array}{l}\text { Regulation of DNA } \\
\text { replication and apoptosis }\end{array}$} & $30(6 / 20)$ & Chile & MSP & Roa et al. 2006 [39] \\
\hline & & & $66(33 / 50)$ & Chile & MSP & Riquelme et al. 2007 [40] \\
\hline & & & $32(8 / 25)$ & Chile & MSP & Roa et al. 2008 [46] \\
\hline & & & $57(13 / 23)$ & Chile & MSP & García et al. 2009 [29] \\
\hline \multirow[t]{5}{*}{$A P C$} & \multirow[t]{5}{*}{ Adenomatous polyposis coli } & \multirow[t]{5}{*}{$\begin{array}{l}\text { Cell migration, adhesion } \\
\text { and apoptosis }\end{array}$} & $26(14 / 54)$ & Chile, USA & $\begin{array}{l}\text { Nested } \\
\text { MSP }\end{array}$ & House et al. 2003 [28] \\
\hline & & & $30(15 / 50)$ & Chile & MSP & Takahashi et al. 2004 [32] \\
\hline & & & $40(8 / 20)$ & Chile & MSP & Roa et al. 2006 [39] \\
\hline & & & $32(8 / 25)$ & Chile & MSP & Roa et al. 2008 [46] \\
\hline & & & $35(8 / 23)$ & Chile & MSP & García et al. 2009 [29] \\
\hline \multirow[t]{6}{*}{ hMLH1 } & \multirow[t]{6}{*}{$\begin{array}{l}\text { Human homologs of the } \\
\text { Mutl gene of bacteria }\end{array}$} & \multirow[t]{6}{*}{ Mismatch repair } & $13(7 / 54)$ & Chile, USA & $\begin{array}{l}\text { Nested } \\
\text { MSP }\end{array}$ & House et al. 2003 [28] \\
\hline & & & $0(0 / 9)$ & Japan & MSP & Tozawa et al. 2004 [43] \\
\hline & & & $5(1 / 20)$ & Chile & MSP & Roa et al. 2006 [39] \\
\hline & & & $4(2 / 50)$ & Chile & MSP & Riquelme et al. 2007 [40] \\
\hline & & & $4(1 / 25)$ & Chile & MSP & Roa et al. 2008 [46] \\
\hline & & & $17(4 / 23)$ & Chile & MSP & García et al. 2009 [29] \\
\hline \multirow[t]{10}{*}{ p16 } & \multirow[t]{10}{*}{$\begin{array}{l}\text { Cyclin-dependent kinase } \\
\text { inhibitor } 2 A\end{array}$} & \multirow[t]{10}{*}{ Cell cycle regulation } & $56(30 / 54)$ & Chile, USA & $\begin{array}{l}\text { Nested } \\
\text { MSP }\end{array}$ & House et al. 2003 [28] \\
\hline & & & $60(3 / 5)$ & Germany & MSP & Klump et al. 2003 [48] \\
\hline & & & $22(2 / 9)$ & Japan & MSP & Tozawa et al. 2004 [43] \\
\hline & & & $24(9 / 38)$ & Chile & MSP & Roa et al. 2004 [49] \\
\hline & & & $24(12 / 50)$ & Chile & MSP & Takahashi et al. 2004 [32] \\
\hline & & & $15(8 / 54)$ & China & MSP & Ueki et al. 2004 [31] \\
\hline & & & $20(4 / 20)$ & Chile & MSP & Roa et al. 2006 [39] \\
\hline & & & $73(37 / 51)$ & Japan & MSP & Tadokoro et al. 2007 [50] \\
\hline & & & $20(5 / 25)$ & Chile & MSP & Roa et al. 2008 [46] \\
\hline & & & $26(6 / 23)$ & Chile & MSP & García et al. 2009 [29] \\
\hline \multirow[t]{2}{*}{ p15 } & \multirow{2}{*}{$\begin{array}{l}\text { Cyclin-dependent kinase } \\
\text { inhibitor } 2 B\end{array}$} & \multirow[t]{2}{*}{ Cell cycle regulation } & $44(22 / 50)$ & Chile & MSP & Takahashi et al. 2004 [32] \\
\hline & & & $22(5 / 23)$ & Chile & MSP & García et al. 2009 [29] \\
\hline \multirow[t]{3}{*}{ DAPK1 } & \multirow{3}{*}{$\begin{array}{l}\text { Death-associated protein } \\
\text { kinase } 1\end{array}$} & \multirow[t]{3}{*}{ Serine-threonine kinase } & $22(2 / 9)$ & Japan & MSP & Tozawa et al. 2004 [43] \\
\hline & & & $8(4 / 50)$ & Chile & MSP & Takahashi et al. 2004 [32] \\
\hline & & & $61(14 / 23)$ & Chile & MSP & García et al. 2009 [29] \\
\hline DLC1 & Deleted in liver cancer 1 & GTPase-activating protein & $39(9 / 23)$ & Chile & MSP & García et al. 2009 [29] \\
\hline \multirow[t]{4}{*}{ RASSF1 } & \multirow{4}{*}{$\begin{array}{l}\text { RAS association domain } \\
\text { family protein } 1 \mathrm{~A}\end{array}$} & \multirow[t]{4}{*}{ Signal transduction } & $11(1 / 9)$ & Japan & MSP & Tozawa et al. 2004 [43] \\
\hline & & & $0(0 / 50)$ & Chile & MSP & Takahashi et al. 2004 [32] \\
\hline & & & $8(4 / 50)$ & Chile & MSP & Riquelme et al. 2007 [40] \\
\hline & & & $36(8 / 22)$ & Korea & MSP & Kee et al. 2007 [42] \\
\hline
\end{tabular}


Table 1 Summary of the methylation rate of multiple genes studied in advanced gallbladder cancer (Continued)

\begin{tabular}{|c|c|c|c|c|c|c|}
\hline & & & $17(4 / 23)$ & Chile & MSP & García et al. 2009 [29] \\
\hline \multirow[t]{2}{*}{ MGMT } & \multirow[t]{2}{*}{$\begin{array}{l}\text { 0-6-methylguanine-DNA } \\
\text { methyltransferase }\end{array}$} & \multirow[t]{2}{*}{ Methyltransferase } & $13(7 / 54)$ & Chile, USA & $\begin{array}{l}\text { Nested } \\
\text { MSP }\end{array}$ & House et al. 2003 [28] \\
\hline & & & $30(7 / 23)$ & Chile & MSP & Garcia et al. 2009 [29] \\
\hline \multirow[t]{2}{*}{$\mathrm{CDH} 13$} & \multirow{2}{*}{$\begin{array}{l}\text { Cadherin 13, H-cadherin } \\
\text { (heart) }\end{array}$} & \multirow{2}{*}{$\begin{array}{l}\text { Tissue invasion } \\
\text { (cell-cell adhesion) }\end{array}$} & $44(22 / 50)$ & Chile & MSP & Takahashi et al. 2004 [32] \\
\hline & & & $70(16 / 23)$ & Chile & MSP & García et al. 2009 [29] \\
\hline \multirow[t]{2}{*}{ TIMP3 } & \multirow[t]{2}{*}{ Metallopeptidase inhibitor 3} & \multirow{2}{*}{$\begin{array}{l}\text { Degradation of the } \\
\text { extracellular matrix }\end{array}$} & $0(0 / 50)$ & Chile & MSP & Takahashi et al. 2004 [32] \\
\hline & & & $39(9 / 23)$ & Chile & MSP & Garcia et al. 2009 [29] \\
\hline GSTP1 & Glutathione S-transferase pi 1 & $\begin{array}{l}\text { Conjugation of hydrophobic } \\
\text { and electrophilic compounds }\end{array}$ & $13(3 / 23)$ & Chile & MSP & Garcia et al. 2009 [29] \\
\hline \multirow[t]{3}{*}{ RARß2 } & \multirow[t]{3}{*}{ Retinoic acid receptor, beta } & \multirow{3}{*}{$\begin{array}{l}\text { Encodes retinoic acid } \\
\text { receptor beta (mediates } \\
\text { cellular signaling) }\end{array}$} & $4(2 / 54)$ & Chile, USA & $\begin{array}{l}\text { Nested } \\
\text { MSP }\end{array}$ & House et al. 2003 [28] \\
\hline & & & $14(7 / 50)$ & Chile & MSP & Takahashi et al. 2004 [32] \\
\hline & & & $44(10 / 23)$ & Chile & MSP & Garcia et al. 2009 [29] \\
\hline REPRIMO & $\begin{array}{l}\text { TP53 dependent G2 arrest } \\
\text { mediator candidate }\end{array}$ & $\begin{array}{l}\text { Cell cycle regulation (p53 } \\
\text { mediator) }\end{array}$ & $62(31 / 50)$ & Chile & MSP & Takahashi et al. 2005 [51] \\
\hline SHP1 & $\begin{array}{l}\text { Protein tyrosine phosphatase, } \\
\text { non-receptor type } 6\end{array}$ & $\begin{array}{l}\text { Regulate cell growth, } \\
\text { differentiation, mitotic cycle }\end{array}$ & $80(40 / 50)$ & Chile & MSP & Takahashi et al. 2004 [32] \\
\hline 3-OST-2 & $\begin{array}{l}\text { Heparan sulfate (glucosamine) } \\
\text { 3-O-sulfotransferase } 2\end{array}$ & Osulfotransferase & $72(36 / 50)$ & Chile & MSP & Takahashi et al. 2004 [32] \\
\hline \multirow[t]{2}{*}{ RUNX3 } & \multirow{2}{*}{$\begin{array}{l}\text { Runt-related transcription } \\
\text { factor } 3\end{array}$} & \multirow[t]{2}{*}{ TGF-beta signal pathway } & $22(2 / 9)$ & Japan & MSP & Tozawa et al. 2004 [43] \\
\hline & & & $32(16 / 50)$ & Chile & MSP & Takahashi et al. 2004 [32] \\
\hline$R I Z 1$ & $\begin{array}{l}\text { PR domain containing 2, } \\
\text { with ZNF domain }\end{array}$ & $\begin{array}{l}\text { Histone/protein } \\
\text { methyltransferase }\end{array}$ & $26(13 / 50)$ & Chile & MSP & Takahashi et al. 2004 [32] \\
\hline HPP1 & $\begin{array}{l}\text { Transmembrane protein with } \\
\text { EGF-like and two follistatin-like } \\
\text { domains } 2\end{array}$ & TGF-beta signal pathway & $20(10 / 50)$ & Chile & MSP & Takahashi et al. 2004 [32] \\
\hline \multirow[t]{2}{*}{ P73 } & \multirow[t]{2}{*}{ Tumor protein $p 73$} & \multirow[t]{2}{*}{$\begin{array}{l}\text { Induction of apoptosis and } \\
\text { cell cycle regulation }\end{array}$} & $28(15 / 54)$ & Chile, USA & $\begin{array}{l}\text { Nested } \\
\text { MSP }\end{array}$ & House et al. 2003 [28] \\
\hline & & & $14(7 / 50)$ & Chile & MSP & Takahashi et al. 2004 [32] \\
\hline SOCS-1 & $\begin{array}{l}\text { Suppressor of cytokine } \\
\text { signaling } 1\end{array}$ & JAK-STAT pathway & $12(6 / 50)$ & Chile & MSP & Takahashi et al. 2004 [32] \\
\hline DCR2 & $\begin{array}{l}\text { Tumor necrosis factor receptor } \\
\text { superfamily, member 10d }\end{array}$ & TNF-receptor superfamily & $6(3 / 50)$ & Chile & MSP & Takahashi et al. 2004 [32] \\
\hline SEMA3B & $\begin{array}{l}\text { Sema domain, } \\
\text { immunoglobulin domain (lg), } \\
\text { short basic domain, secreted, } \\
\text { (semaphorin) } 3 B\end{array}$ & Induction of apoptosis & $92(46 / 50)$ & Chile & MSP & Riquelme et al. 2007 [40] \\
\hline DUTT1 & $\begin{array}{l}\text { Human homolog of } \\
\text { Drosophila Roundabout } \\
\text { (ROBO1) }\end{array}$ & $\begin{array}{l}\text { Cell migration } \\
\text { and metastasis }\end{array}$ & $22(11 / 50)$ & Chile & MSP & Riquelme et al. 2007 [40] \\
\hline$B L U$ & $\begin{array}{l}\text { Zinc finger, MYND-type } \\
\text { containing } 10\end{array}$ & Cell cycle regulation & $26(13 / 50)$ & Chile & MSP & Riquelme et al. 2007 [40] \\
\hline UCHL1 & $\begin{array}{l}\text { Ubiquitin carboxyl - terminal } \\
\text { esterase L1 }\end{array}$ & Peptidase C12 family & $27(6 / 22)$ & Korea & MSP & Lee et al. 2006 [52] \\
\hline p14 & $\begin{array}{l}\text { Ribonuclease P/MRP } 14 \mathrm{kDa} \\
\text { subunit }\end{array}$ & Cell cycle regulation & $40(2 / 5)$ & Germany & MSP & Klump et al. 2003 [48] \\
\hline
\end{tabular}

JAK-STAT: janus kinase-signal transducer and activator of transcription; MSP: methylation specific PCR; TGF: transforming growth factor; TNF: tumor necrosis factor.

this situation in RUNX3, with $78.3 \%$ methylation in carcinoma of the biliary duct compared with $22.2 \%$ in GBC [43].
Recently it has been reported that PSCA is downregulated in non-neoplastic gallbladder lesions such as cholesterolosis, cholecystolithiasis and cholecystitis (9 out of 
17; 53\%). However, it was disclosed that the expression was decreased in more than $90 \%$ of cancers (40 out of 44) [53]. A DNA methylation assay revealed that the methylation level of the gene enhancer region was comparatively low in the cell lines of GBC with a relatively higher PSCA expression, suggesting that the methylation level of the region is related to the level of PSCA expression [53]. However, in the four GBC samples, no correlation was detected between the PSCA expression level and the DNA methylation level of the PSCA enhancer [53]. In others tumors, such as prostate and pancreatic cancers and gliomas, PSCA was recently reported to be upregulated [54], which suggests that PSCA has a different function dependent on the type of cancer. However, its function in normal and malignant epithelial cells is unknown.

\section{DNA promoter methylation of specific genes}

Alterations in DNA methylation patterns are commonly found in all cancers, often with concomitant changes in gene expression. In GBC, molecular information is reduced; however, a high rate of methylation of some genes in GBC has been reported and associated with carcinogenesis of other tissues of the human digestive tract.

\section{$\mathrm{CDH} 1$}

The E-cadherin gene (CDH1), located on chromosome $16 q 22.1$, is one of the most important tumor suppressor genes [55,56]. CDH1 encodes for a transmembrane glycoprotein of $120 \mathrm{kDa}$ that intervenes in cell adhesion mediated by calcium. It is a component of the E-cadherin /beta-catenin complex, which is important for cellular polarity, normal tissue morphology and cellular differentiation [56]. It also integrates adherens junctions (originally known as belt desmosomes) that form a continuous belt around the cell to bind the epithelial cells to each other and to maintain the integrity of the stratified epithelium [56]. CDH1 belongs to a family of genes directly related to the processes of tumor invasion and cytoskeleton destabilization. CDH1 expression, it has been reported in less differentiated tumors, that generally have an unfavorable prognosis $[57,58]$. The most aggressive carcinomas generally show losses of epithelial cell cohesion, and this is often associated with a reduction in E-cadherin expression [59]. Some mutations of this gene have been detected in gastric, breast and endometrial cancer $[60,61]$. The methylation rate of different tumor suppressor genes in cancers of the digestive tract (stomach, colon, pancreas and gallbladder) has been studied, and show a high methylation frequency of CDH1 (77.8\%) [46]. CDH1 has been described to be hypermethylated in GBC (Table 1), with frequencies that range from $11.1 \%$ to $65.2 \%$ [29,32,39,43,46,47]. Likewise, the methylation of this gene in advanced stage III and IV of GBC was evaluated, demonstrating approximately 60\% methylation [46]. Previously, we reported that reduced expression of E-cadherin in resected gallbladder cancer tissues was significantly correlated with poor prognosis [62]. Loss of E-cadherin expression, followed by expression of the mts1 gene, may be an important event for increasing cell proliferation, motility and invasion activity in the progression of gallbladder cancer [63].

In relation to the degree of tumor differentiation, it was observed that $C D H 1$ presented a high methylation frequency in poorly differentiated tumors and in cases with three or more positive nodes [46]. A significant decrease in $C D H 1$ expression has been recorded as the lesion progresses, which may be due to methylation [39]. As far as patient survival is concerned, this gene does not exhibit significant differences in survival between the methylated and non-methylated cases [29,39].

Therefore, there is a significant correlation between the methylation of $\mathrm{CDH} 1$ and the metastatic phenotype in GBC [32], which has already been described in previous studies on breast cancer [64].

Hypermethylation of $C D H 1$ has been reported in two cell lines of biliary tract cancer (SNU-478 and SNU1079), with silenced mRNA expression. After treatment with a demethylating agent (5-aza-2'-deoxycytidine), $C D H 1$ was successfully re-expressed [65].

\section{CDKN2A-p 16}

$C D K N 2 A-p 16$ is a tumor suppressor gene that encodes the protein p16, which is an inhibitor of cyclindependent kinase, involved in cell cycle regulation at Checkpoint G1. The loss of p16 expression is usually connected to homozygote deletion, loss of heterozygosity, mutations and methylation. A lower expression of p16 has been reported to increase the activity of D-type cyclin-dependent kinase activity, which translates into aberrant phosphorylation of the retinoblastoma gene, producing uncontrolled cell proliferation $[31,46]$. Loss of heterozygosity and homozygote deletion are two different pathways of p16 inactivation and have been shown to be combined with hypermethylation of the promoter in GBC [50]. In hepatocellular carcinoma and intrahepatic cholangiocarcinoma, $p 16$ is frequently inactivated by methylation of the promoter and rarely by deletion or mutation [31]. Inactivation of p16 through methylation of the promoter region has been frequently identified in breast, prostate, head and neck, liver, lung, brain, colon and esophageal cancers and cell lines of bladder cancer [66-69]. This is a tendency that is also observed in GBC with a loss of expression of up to $62.5 \%$ [48,50]. Takahashi et al. [32] reported that a considerable number of genes (8 out of 24 genes) are frequently methylated in GBC in 
comparison with chronic cholecystitis, varying in methylation frequency between $4 \%$ and $80 \%$, with p16 having the lowest rate [32].

In 2006, Roa et al. published the methylation status of five genes in advanced carcinoma of the gallbladder and their correlation with the immunohistochemical expression, demonstrating that CDH1, APC, FHIT and CDKN2A might be important in the carcinogenesis of gallbladder [39]. Hypermethylation of $C D K N 2 A$ is also one of the main mechanisms that induce the loss of p16 expression [49]. Furthermore, Ueki et al. studied different alterations of $p 16$ in 68 tumors in Chinese patients, finding that only $14.8 \%$ presented aberrant hypermethylation [31]. Other investigations have identified a methylation percentage of $72.5 \%$ at different stages of progression; nevertheless, a significant relationship to the loss of expression of this protein was not established [50]. When the methylation state of this gene was evaluated in samples from the US and Chile, methylation frequencies of $56 \%$ were recorded, with similar methylation patterns in both populations [28].

In the analysis of $p 16$ and $p 14$, it was noted that they presented a high methylation rate (between $40 \%$ and $60 \%$ ) for carcinoma of the biliary duct, GBC and for primary sclerosing cholangitis. In normal tissue and choledocolithiasis, either no or an extremely low methylation rate was observed in the two genes [48].

The absence of alterations in p16 (methylation, mutation, loss of heterozygosity in chromosome 9p) in cases of GBC means a better overall survival rate, and it is thus considered a significant prognostic factor [31]. A similar relationship has been seen in patients with stage IA non-small cell lung cancer, where the hypermethylation of $p 16$ was related to poorer survival [70]. This was not the case for other cancers (for example, of the biliary duct and the ampulla of vater), where the alteration had no influence on the prognosis [31].

\section{Reprimo}

This is a candidate tumor suppressor gene regulating p53, which is commonly altered in numerous human cancers. Reprimo is a highly glycosylated protein located in the cytoplasm that induces cell cycle arrest at the G2 phase, inhibiting the activity of $\mathrm{Cdc} 2$ and cyclin B1 $[71,72]$. The transcriptional repression of Reprimo by methylation was initially confirmed together with other genes in pancreatic cancer [72]. In addition, it was found to be hypermethylated in 16 different types of tumors, with a high percentage in gastric cancer (79\%), gallbladder cancer (62\%), lymphoma (57\%), colorectal cancer (56\%), esophageal adenocarcinoma (40\%), breast cancer (37\%) and leukemia (31\%) [51]. As a result, it has been described as a potential biomarker for the early detection of gastric cancer [73].
Hypermethylation of this gene is infrequent in normal tissue; however, methylation percentages of $32 \%$ and $27 \%$ have been described in the gastric epithelium and colorectal polyps, respectively [51]. A low methylation pattern in close to $4 \%$ of cases has been described in chronic cholecystitis samples [51].

\section{UCHL 1}

UCHL1 (also known as PGP9.5) is the only gene with a potential oncogenic role that has found to be hypomethylated in the promoter region in GBC [52]. Is located on chromosome 4p14 and was identified originally as a member of a gene family whose products hydrolyze small C-terminal adducts of ubiquitin (Ub) to generate the ubiquitin monomer [74]. The product of the gene is a peptide responsible for eliminating $\mathrm{Ub}$ from proteins that have it, and to thereby avoid its degradation by the proteasome. Proteins degraded by this mechanism actively participate in cell cycle control, for example, p53 and a variety of cyclins [75]. Ub, a protein consisting of 76 amino acid residues, is present in all eukaryotic cells tested. It plays a role in the degradation of abnormal and short-lived proteins by the ATP- and Ub-dependent proteolytic systems. UCHL1 dysfunction in neurons is known to be involved in familial Parkinson's disease [76]. In vivo analysis of UCHL1-deficient mice suggested that it functions as a regulator of apoptosis in neurons [77] and also in germinal cells during spermatogenesis [78].

The accumulation of Ub has been documented in several types of primary cancers [75]. During the past few years, several works have reported the link between UCHL1 expression and tumor progression, and that it may be useful as a potential marker of several human cancers, such as non-small cell lung cancer $[79,80]$, invasive colorectal cancer [81], pancreatic cancer [82], squamous cell esophageal carcinoma [83] and neuroblastoma [84]. In GBC, a progressive decrease in the methylation of this gene has been observed, with $84.6 \%$ in normal epithelium, $37.5 \%$ in adenoma and $27.2 \%$ in carcinoma. These results suggest that hypomethylation of the PGP9.5 promoter is a reliable marker in GBC and that DNA hypomethylation might play a significant role in the re-expression of the gene in GBC [52]. In addition, hypomethylation of UCHL1 had previously been found in its promoter region in colorectal cancer, and lymph node metastasis was significantly associated with a lower frequency of methylation [85], poorer survival and a high incidence of recurrence [86].

\section{Discussion}

DNA methylation is the epigenetic alteration most studied in the cancer cell. The number of genes with aberrant methylation in the human cancer cell is not known, 
but it is estimated that around 1\% (or 250 genes) of the human genome can be aberrantly methylated in a tumor cell [87]. The use of methylation in the search for new biomarkers in GBC is a promising alternative since this epigenetic modification is an early, progressive and cumulative event in GBC. The methylation frequency of promoter regions of some important tumor suppressor genes, such as p16, CDH1, REPRIMO, DAPK-1 and $S E M A 3 B$, is high in GBC $[29,40,48,50,51,88]$, and has also been well documented in other cancers.

The tumor suppressor gene $p 16$ is frequently inactivated in a wide variety of human cancers by at least three distinct mechanisms: point mutation, small deletions of both $p 16$ alleles, and methylation of $\mathrm{CpG}$ islands [89]. Other studies have found methylation of the $p 16$ promoter in two of eight (25\%) cholangiocarcinomas, and four of seven (57\%) tumors analyzed by immunohistochemistry, demonstrated an absence of p16 nuclear staining in primary sclerosing cholangitis-associated cholangiocarcinoma [89]. Also, a high frequency of methylation (36 out of $72 ; 50 \%$ ) has been reported in cases of intrahepatic and extrahepatic cholangiocarcinoma [45]. The expression of E-cadherin frequently diminishes as the tumor progresses, and abnormalities of E-cadherin expression have been associated with decreased apoptosis in GBC [88] and genomic instability during the process of neoplastic transformation [90]. In cholangiocarcinoma, mutations of $C D H 1$ are rare events [91]. Downregulation of E-cadherin expression is more commonly mediated through DNA methylation, with frequencies between $40 \%$ and $48 \%$ [45,92,93], while in GBC the frequency is between $11 \%$ and $65 \%[29,43]$. This variation could be directly related to ethnic differences. Tadokoro et al. [50] found a frequency of 73\% of methylation in p16 in samples from Japan, and Takahashi et al. [32] a frequency of $24 \%$ in samples from Chile. The age of the patients could also introduce variations in results. Methylation of $R U N X 3$ was more frequent in elderly patients [43]; environmental factors such as tobacco smoking [94] and Helicobacter pylori infection [95] can accelerate DNA methylation. E-cadherin methylation is an early event in gastric carcinogenesis, and is initiated by $H$. pylori infection [95]. Another possible reason for the variation could be differences in the methodology of study (MSP). House et al. [28] and Koga et al. [47] utilized a two-step MSP method, using nested PCR to increase the sensitivity of detecting allelic hypermethylation of targeted sequences and to facilitate the examination of multiple gene loci, and so the sensitivity in their studies tended to be higher than other studies that used single-step MSP [28]. All researchers used MSP technique for detection of DNA methylation, except Ono et al. [53], who used bisulfite-pyrosequencing in GBC cell lines.
MSP in its classical format is non-quantitative and cannot distinguish between low and high levels of a methylated target sequence. By contrast, combining realtime PCR probes with MSP, as in MethyLight assay, can achieve a quantitative assessment of the level of DNA methylation of a targeted sequence [96]. The effects of bisulfite treatment on DNA are difficult to control and often result in significant DNA degradation of up to $85 \%$ to $95 \%$ of target sequences [96], which would require the use of more sensitive techniques in the detection of potential biomarkers in clinical practice.

UCHL1 is a controversial molecule from an oncologic point of view. Hypomethylation of its promoter has been identified in a subset of human cancers, including GBC, presumably due to its intrinsic oncogenic properties or as a result of transformation. However, UCHL1 has been reported to be repressed by methylation in other cancers, such as primary head and neck squamous cell carcinoma [97] and colorectal, ovarian [98] and pancreatic cancers [72]. Particularly, overexpression of UCHL1 has been found in pancreatic cancers [82] and it is associated with a poor prognosis, so the functional consequences of UCHL1 have yet to be determined.

\section{Conclusions}

Chile is considered a very high-risk area for $\mathrm{GBC}$, and its mortality rate reached 16.5 out 100,000 women in 2007 [99]. It is important to mention the paucity of examinations that enable the diagnosis of this neoplasia in the early stages, with vesicular lithiasis being the most serious risk factor in the metaplasia-dysplasia-carcinoma sequence. In the event of symptoms of acute cholecystitis, the main imaging finding that justifies the indication of elective or emergency cholecystectomy is lithiasis. In many cases, the cancer diagnosis is made based on findings in the anatomopathological examination of the surgical specimen. This explains the current health care policies in force in Chile since 2006, where elective cholecystectomy tends to be performed within guaranteed timeframes in women between 35 and 49 years of age who suffer from lithiasis, in an attempt to reduce the incidence of GBC or to increase the number of cases diagnosed at an early stage. This suggests the need to look for new methodologies that can assess the risk of progression to cancer in patients with preneoplastic lesions and/or clinical-morphological risk factors already known for GBC (such as female, obesity, ethnic group, cholecystolithiasis, gallstone volume, anomalous pancreaticobiliary junction, among others) [3].

Therefore, the study of gene methylation has at least five potential clinical applications: reactivating genes inactivated by methylation using demethylating drugs; identifying tumor cells in biological samples, allowing an early diagnosis since the change in methylation 
frequently precedes the appearance of advanced tumors; determining the methylation of individual genes or methylation profiles for groups of specific genes; being used as response markers to chemo- or hormone therapy; and allowing the transition between neoplastic and normal tissue to be determined in the surgical section margins according to the gene methylation profile $[96,100,101]$. Each of these, either separately or together, takes on special relevance in $\mathrm{GBC}$, because they represent a problem that has scarcely been resolved in the three high-priority areas of oncology research: prevention, early diagnosis, and treatment.

Finally, the reversible nature of the epigenetic changes that occur in cancer must be mentioned as these have made epigenetic therapy possible as a treatment option. This therapy is based on reversing the epigenetic modifications that occur in tumor cells and re-establishing a normal epigenome. The possibility of reversing DNA methylation and reactivating the affected genes is an attractive option for a new therapeutic target in the treatment of cancer or preneoplastic lesions. However, the main problem with demethylating drugs is their poor specificity and they therefore cannot be used in the treatment of previously selected genes [102]. Nevertheless, satisfactory results have been reported regarding the use of epigenetic therapy in patients with myelodysplastic syndrome, approved by the Food and Drug Administration in 2004. This therefore opens a new therapeutic approach in the field of oncology that must be evaluated with multicentric clinical trials.

\section{Competing interests}

The authors declare that they have no competing of interests.

\section{Authors' contributions}

$\mathrm{PL}$ designed the article and participated in writing all sections of the manuscript. PB revised the manuscript and contributed to content relating to methylation studies on the gallbladder cancer. OT contributed to content relating to conclusions and provided guidance for the structure. JCR provided guidance for the overall structure and content of the manuscript. All authors read and approved the final manuscript.

\section{Acknowledgments}

$\mathrm{PL}, \mathrm{PB}, \mathrm{OT}$ and JR were supported by CORFO, Proyecto Creación del centro de excelencia en estudios genéticos e inmunológicos (CEGIN) 09CN14-5960, Scientific and Technological Bioresource Nucleus (BIOREN); PL is the recipient of grants from the Comisión Nacional de Investigación Científica y Tecnológica (CONICYT) 21090324, 24110125 and 29110082; PB is the recipient of grants from the Fondo Nacional de Desarrollo Científico y Tecnológico (FONDECYT) Proyecto Postdoctorado 3120141 and Fondo de Fomento al Desarrollo Científico y Tecnológico (FONDEF) VIU110036. OT is supported by FONDECYT 11110239; JR is supported by FONDECYT 1090171.

\section{Author details}

'Universidad de La Frontera, School of Medicine, Department of Pathology, Molecular Pathology Laboratory, BIOREN-CEGIN, Temuco, Chile. ${ }^{2}$ Pontificia Universidad Católica de Chile, School of Medicine, Department of Pathology, Santiago, Chile. ${ }^{3}$ Department of Pathology, Hospital Hernán Henríquez Aravena, Temuco, Chile. ${ }^{4}$ Department of Pathology, School of Medicine, Universidad de La Frontera, Manuel Montt 112 of 211, Temuco, Chile.
Received: 3 April 2012 Accepted: 8 June 2012

Published: 13 July 2012

\section{References}

1. Roa I, Araya JC, Villaseca M, Roa J, de Aretxabala X, Ibacache G: Gallbladder cancer in a high risk area: morphological features and spread patterns. Hepatogastroenterology 1999, 46:1540-1546.

2. Misra S, Chaturvedi A, Misra NC, Sharma ID: Carcinoma of the gallbladder. Lancet Oncol 2003, 4:167-176.

3. Stinton LM, Shaffer EA: Epidemiology of gallbladder disease: cholelithiasis and cancer. Gut Liver 2012, 6:172-187.

4. Goldin RD, Roa JC: Gallbladder cancer: a morphological and molecular update. Histopathology 2009, 55:218-229.

5. Roa I, Araya JC, Wistuba I, Villaseca M, de Aretxabala X, Burgos L: Gallbladder cancer in the IX Region of Chile. Impact of the anatomopathological study of 474 cases. Rev Med Chil 1994 122:1248-1256.

6. Fernandez M, Csendes A, Yarmuch J, Diaz H, Silva J: Management of common bile duct stones: the state of the art in 2000. Int Surg 2003, 88:159-163.

7. Lazcano-Ponce EC, Miquel JF, Munoz N, Herrero R, Ferrecio C, Wistuba II, Alonso de Ruiz P, Aristi Urista G, Nervi F: Epidemiology and molecular pathology of gallbladder cancer. CA Cancer J Clin 2001, 51:349-364.

8. Chow WH, Johansen C, Gridley G, Mellemkjaer L, Olsen JH, Fraumeni JF Jr: Gallstones, cholecystectomy and risk of cancers of the liver, biliary tract and pancreas. Br J Cancer 1999, 79:640-644.

9. Macarthur M, Hold GL, El-Omar EM: Inflammation and Cancer II. Role of chronic inflammation and cytokine gene polymorphisms in the pathogenesis of gastrointestinal malignancy. Am J Physiol Gastrointest Liver Physiol 2004, 286:G515-520.

10. Aldridge $\mathrm{MC}$, Bismuth $\mathrm{H}$ : Gallbladder cancer: the polyp-cancer sequence. Br J Surg 1990, 77:363-364.

11. Roa I, de Aretxabala X, Araya JC, Villaseca M, Roa J, Guzman P: Incipient gallbladder carcinoma. Clinical and pathological study and prognosis in 196 cases. Rev Med Chil 2001, 129:1113-1120.

12. Gourgiotis S, Kocher HM, Solaini L, Yarollahi A, Tsiambas E, Salemis NS: Gallbladder cancer. Am J Surg 2008, 196:252-264.

13. Kozuka S, Tsubone N, Yasui A, Hachisuka K: Relation of adenoma to carcinoma in the gallbladder. Cancer 1982, 50:2226-2234.

14. Wistuba II, Sugio K, Hung J, Kishimoto Y, Virmani AK, Roa I, Albores-Saavedra J, Gazdar AF: Allele-specific mutations involved in the pathogenesis of endemic gallbladder carcinoma in Chile. Cancer Res 1995, 55:2511-2515.

15. Roa JC, Roa I: Preneoplastic lesions of a gallbladder from morphological and molecular points of view. In New Research on Precancerous Conditions. Edited by Litchfield J. New York: Nova; 2007.

16. Esteller M: Epigenetics in cancer. N Engl J Med 2008, 358:1148-1159.

17. Feinberg AP, Tycko B: The history of cancer epigenetics. Nat Rev Cancer 2004, 4:143-153.

18. Kawasaki H, Taira K: Transcriptional gene silencing by short interfering RNAs. Curr Opin Mol Ther 2005, 7:125-131.

19. Khalil AM, Wahlestedt C: Epigenetic mechanisms of gene regulation during mammalian spermatogenesis. Epigenetics 2008, 3:21-28.

20. Rodríguez MTN, Cerbón M: Metilación del ADN: un fenómeno epigenético de importancia médica. Rev Investig Clin 2004, 56:56-71.

21. Esteller M, Fraga MF, Guo M, Garcia-Foncillas J, Hedenfalk I, Godwin AK, Trojan J, Vaurs-Barriere C, Bignon YJ, Ramus S, Benitez J, Caldes T, Akiyama Y, Yuasa Y, Launonen V, Canal MJ, Rodriguez R, Capella G, Peinado MA, Borg A, Aaltonen LA, Ponder BA, Baylin SB, Herman JG: DNA methylation patterns in hereditary human cancers mimic sporadic tumorigenesis. Hum Mol Genet 2001, 10:3001-3007.

22. Jones PA, Laird PW: Cancer epigenetics comes of age. Nat Genet 1999, 21:163-167.

23. Antequera F, Bird A: Number of CpG islands and genes in human and mouse. Proc Natl Acad Sci U S A 1993, 90:11995-11999.

24. Serman A, Vlahovic M, Serman L, Bulic-Jakus F: DNA methylation as a regulatory mechanism for gene expression in mammals. Coll Antropol 2006, 30:665-671.

25. Jang $H$, Mason JB, Choi SW: Genetic and epigenetic interactions between folate and aging in carcinogenesis. J Nutr 2005, 135:2967S-2971S.

26. Esteller M, Herman JG: Cancer as an epigenetic disease: DNA methylation and chromatin alterations in human tumours. J Pathol 2002, 196:1-7. 
27. Brait M, Sidransky D: Cancer epigenetics: above and beyond. Toxicol Mech Methods 2011, 21:275-288.

28. House MG, Wistuba II, Argani P, Guo M, Schulick RD, Hruban RH, Herman JG, Maitra A: Progression of gene hypermethylation in gallstone disease leading to gallbladder cancer. Ann Surg Oncol 2003, 10:882-889.

29. Garcia P, Manterola C, Araya JC, Villaseca M, Guzman P, Sanhueza A, Thomas M, Alvarez H, Roa JC: Promoter methylation profile in preneoplastic and neoplastic gallbladder lesions. Mol Carcinog 2009, 48:79-89.

30. Shin SH, Lee K, Kim BH, Cho NY, Jang JY, Kim YT, Kim D, Jang JJ, Kang GH: Bile-based detection of extrahepatic cholangiocarcinoma with quantitative DNA methylation markers and its high sensitivity. J Mol Diagn 2012, 14:256-263.

31. Ueki T, Hsing AW, Gao YT, Wang BS, Shen MC, Cheng J, Deng J, Fraumeni JF Jr, Rashid A: Alterations of p16 and prognosis in biliary tract cancers from a population-based study in China. Clin Cancer Res 2004, 10:1717-1725

32. Takahashi T, Shivapurkar N, Riquelme E, Shigematsu H, Reddy J, Suzuki M, Miyajima K, Zhou X, Bekele BN, Gazdar AF, Wistuba II: Aberrant promoter hypermethylation of multiple genes in gallbladder carcinoma and chronic cholecystitis. Clin Cancer Res 2004, 10:6126-6133.

33. Roa I, de Aretxabala X, Araya JC, Roa J: Preneoplastic lesions in gallbladder cancer. J Surg Oncol 2006, 93:615-623.

34. Hong SH, Kim HG, Chung WB, Kim EY, Lee JY, Yoon SM, Kwon JG, Sohn YK, Kwak EK, Kim JW: DNA hypermethylation of tumor-related genes in gastric carcinoma. J Korean Med Sci 2005, 20:236-241.

35. Maruyama R, Toyooka S, Toyooka KO, Virmani AK, Zochbauer-Muller S, Farinas AJ, Minna JD, McConnell J, Frenkel EP, Gazdar AF: Aberrant promoter methylation profile of prostate cancers and its relationship to clinicopathological features. Clin Cancer Res 2002, 8:514-519.

36. Wong CM, Lee JM, Ching YP, Jin DY, Ng IO: Genetic and epigenetic alterations of DLC-1 gene in hepatocellular carcinoma. Cancer Res 2003, 63:7646-7651

37. Xu XL, Yu J, Zhang HY, Sun MH, Gu J, Du X, Shi DR, Wang P, Yang ZH, Zhu JD Methylation profile of the promoter CpG islands of 31 genes that may contribute to colorectal carcinogenesis. World J Gastroenterol 2004 10:3441-3454

38. Esteller M: Aberrant DNA methylation as a cancer-inducing mechanism. Annu Rev Pharmacol Toxicol 2005, 45:629-656.

39. Roa JC, Anabalon L, Roa I, Melo A, Araya JC, Tapia O, de Aretxabala X, Munoz S, Schneider B: Promoter methylation profile in gallbladder cancer. J Gastroenterol 2006, 41:269-275.

40. Riquelme E, Tang M, Baez S, Diaz A, Pruyas M, Wistuba II, Corvalan A Frequent epigenetic inactivation of chromosome $3 p$ candidate tumor suppressor genes in gallbladder carcinoma. Cancer Lett 2007, 250:100-106.

41. Dammann R, Schagdarsurengin U, Seidel C, Strunnikova M, Rastetter M, Baier K, Pfeifer GP: The tumor suppressor RASSF1A in human carcinogenesis: an update. Histol Histopathol 2005, 20:645-663.

42. Kee SK, Lee JY, Kim MJ, Lee SM, Jung YW, Kim YJ, Park JY, Bae HI, Hong HS, Yun YK, Kim SG, Kim DS: Hypermethylation of the Ras association domain family 1A (RASSF1A) gene in gallbladder cancer. Mol Cells 2007, 24:364-371.

43. Tozawa T, Tamura G, Honda T, Nawata S, Kimura W, Makino N, Kawata S, Sugai T, Suto T, Motoyama T: Promoter hypermethylation of DAP-kinase is associated with poor survival in primary biliary tract carcinoma patients. Cancer Sci 2004, 95:736-740.

44. Chen YJ, Tang QB, Zou SQ: Inactivation of RASSF1A, the tumor suppressor gene at 3p21.3 in extrahepatic cholangiocarcinoma. World J Gastroenterol 2005, 11:1333-1338.

45. Yang B, House MG, Guo M, Herman JG, Clark DP: Promoter methylation profiles of tumor suppressor genes in intrahepatic and extrahepatic cholangiocarcinoma. Mod Pathol 2005, 18:412-420.

46. Roa SJ, Garcia MP, Melo AA, Tapia EO, Villaseca HM, Araya OJ, Guzman GP: Gene methylation patterns in digestive tumors. Rev Med Chil 2008, 136:451-458.

47. Koga Y, Kitajima Y, Miyoshi A, Sato K, Kitahara K, Soejima H, Miyazaki K: Tumor progression through epigenetic gene silencing of $O(6)$ methylguanine-DNA methyltransferase in human biliary tract cancers. Ann Surg Oncol 2005, 12:354-363.

48. Klump B, Hsieh CJ, Dette S, Holzmann K, Kiebetalich R, Jung M, Sinn U, Ortner M, Porschen R, Gregor M: Promoter methylation of INK4a/ARF as detected in bile-significance for the differential diagnosis in biliary disease. Clin Cancer Res 2003, 9:1773-1778.

49. Roa JC, Vo Q, Araya JC, Villaseca M, Guzman P, Ibacache GS, de Aretxabala $X$, Roa I: Inactivation of CDKN2A gene ( 16 ) in gallbladder carcinoma. Rev Med Chil 2004, 132:1369-1376.

50. Tadokoro H, Shigihara T, Ikeda T, Takase M, Suyama M: Two distinct pathways of p16 gene inactivation in gallbladder cancer. World J Gastroenterol 2007, 13:6396-6403.

51. Takahashi T, Suzuki M, Shigematsu H, Shivapurkar N, Echebiri C, Nomura M, Stastny V, Augustus M, Wu CW, Wistuba II, Meltzer SJ, Gazdar AF: Aberrant methylation of Reprimo in human malignancies. Int J Cancer 2005, 115:503-510.

52. Lee YM, Lee JY, Kim MJ, Bae HI, Park JY, Kim SG, Kim DS: Hypomethylation of the protein gene product 9.5 promoter region in gallbladder cancer and its relationship with clinicopathological features. Cancer Sci 2006, 97:1205-1210

53. Ono H, Hiraoka N, Lee YS, Woo SM, Lee WJ, Choi IJ, Saito A, Yanagihara K, Kanai Y, Ohnami S, Chiwaki F, Sasaki H, Sakamoto H, Yoshida T, Saeki N: Prostate stem cell antigen, a presumable organ-dependent tumor suppressor gene, is down-regulated in gallbladder carcinogenesis. Genes Chromosomes Cancer 2012, 51:30-41.

54. Geiger KD, Hendruschk S, Rieber EP, Morgenroth A, Weigle B, Juratli T, Senner $V$, Schackert $G$, Temme A: The prostate stem cell antigen represents a novel glioma-associated antigen. Oncol Rep 2011, 26:13-21.

55. Huntsman DG, Caldas C: Assignment1 of the E-cadherin gene $(\mathrm{CDH} 1)$ to chromosome $16 q 22.1$ by radiation hybrid mapping. Cytogenet Cell Genet 1998, 83:82-83.

56. Semb H, Christofori G: The tumor-suppressor function of E-cadherin. Am J Hum Genet 1998, 63:1588-1593.

57. Dulaimi E, Uzzo RG, Greenberg RE, Al-Saleem T, Cairns P: Detection of bladder cancer in urine by a tumor suppressor gene hypermethylation panel. Clin Cancer Res 2004, 10:1887-1893.

58. Widschwendter A, Ivarsson L, Blassnig A, Muller HM, Fiegl H, Wiedemair A, Müller-Holzner E, Goebel G, Marth C, Widschwendter M: CDH1 and CDH13 methylation in serum is an independent prognostic marker in cervical cancer patients. Int J Cancer 2004, 109:163-166.

59. Santos Garcia A, Abad Hernandez MM, Fonseca Sánchez E, Julián Gonzalez R, Galindo Villardón P, Cruz Hernández JJ, Bullón Sopelana A: Expresión de E-cadherina, laminina y colágeno IV en la evolución de displasia a carcinoma epidermoide oral [E-cadherina, laminin and collagen IV expression in the evolution from dysplasia to oral squamous cell carcinoma]. Med Oral Patol Oral Cir Bucal 2006, 11(2):e100-e105.

60. Berx G, Nollet F, van Roy F: Dysregulation of the E-cadherin/catenin complex by irreversible mutations in human carcinomas. Cell Adhes Commun 1998, 6:171-184.

61. Mărgineanu $E_{1}$ Cotrutz $C E$, Cotrutz C: Correlation between E-cadherin abnormal expressions in different types of cancer and the process of metastasis. Rev Med Chir Soc Med Nat lasi 2008, 112(2):432-436.

62. Mori M, Miyazaki K, Oji K, Itahara K, Mukai S, Motoyama K, Edakuni G: Relationship between prognosis of gallbladder carcinoma patients and the expression of E-cadherin/.ALPHA.-catenin. Japanese Journal of Gastroenterological Surgery 2000, 33:584-589.

63. Kohya N, Kitajima Y, Jiao W, Miyazaki K: Effects of E-cadherin transfection on gene expression of a gallbladder carcinoma cell line: repression of MTS1/S100A4 gene expression. Int J Cancer 2003, 104:44-53.

64. Oka H, Shiozaki H, Kobayashi K, Inoue M, Tahara H, Kobayashi T, Takatsuka Y, Matsuyoshi N, Hirano S, Takeichi M, Mori T: Expression of E-cadherin cell adhesion molecules in human breast cancer tissues and its relationship to metastasis. Cancer Res 1993, 53:1696-1701.

65. Ku JL, Yoon KA, Kim IJ, Kim WH, Jang JY, Suh KS, Kim SW, Park YH, Hwang $J H$, Yoon YB, Park JG: Establishment and characterisation of six human biliary tract cancer cell lines. Br J Cancer 2002, 87:187-193.

66. Herman JG, Merlo A, Mao L, Lapidus RG, Issa JP, Davidson NE, Sidransky D, Baylin SB: Inactivation of the CDKN2/p16/MTS1 gene is frequently associated with aberrant DNA methylation in all common human cancers. Cancer Res 1995, 55:4525-4530.

67. El-Naggar AK, Lai S, Clayman G, Lee JK, Luna MA, Goepfert H, Batsakis JG: Methylation, a major mechanism of p16/CDKN2 gene inactivation in head and neck squamous carcinoma. Am J Pathol 1997, 151:1767-1774. 
68. Matsuda Y, Ichida T, Matsuzawa J, Sugimura K, Asakura H: p16(INK4) is inactivated by extensive CpG methylation in human hepatocellular carcinoma. Gastroenterology 1999, 116:394-400.

69. Liggett WH Jr, Sidransky D: Role of the p16 tumor suppressor gene in cancer. J Clin Oncol 1998, 16:1197-1206.

70. Yoshino M, Suzuki M, Tian L, Moriya Y, Hoshino H, Okamoto T, Yoshida S, Shibuya K, Yoshino l: Promoter hypermethylation of the p16 and Wif-1 genes as an independent prognostic marker in stage IA non-small cell lung cancers. Int J Oncol 2009, 35:1201-1209.

71. Ohki R, Nemoto J, Murasawa H, Oda E, Inazawa J, Tanaka N, Taniguchi T: Reprimo, a new candidate mediator of the p53-mediated cell cycle arrest at the G2 phase. J Biol Chem 2000, 275:22627-22630.

72. Sato N, Fukushima N, Maitra A, Matsubayashi H, Yeo CJ, Cameron JL, Hruban RH, Goggins M: Discovery of novel targets for aberrant methylation in pancreatic carcinoma using high-throughput microarrays. Cancer Res 2003, 63:3735-3742.

73. Bernal C, Aguayo F, Villarroel C, Vargas M, Diaz I, Ossandon FJ, Santibanez E, Palma M, Aravena E, Barrientos C, Corvalan AH: Reprimo as a potential biomarker for early detection in gastric cancer. Clin Cancer Res 2008, 14:6264-6269

74. Liu Y, Fallon L, Lashuel HA, Liu Z, Lansbury PT Jr: The UCH-L1 gene encodes two opposing enzymatic activities that affect alpha-synuclein degradation and Parkinson's disease susceptibility. Cell 2002, 111:209-218.

75. Ishibashi Y, Takada K, Joh K, Ohkawa K, Aoki T, Matsuda M: Ubiquitin immunoreactivity in human malignant tumours. Br J Cancer 1991, 63:320-322.

76. Leroy E, Boyer R, Auburger G, Leube B, Ulm G, Mezey E, Harta G, Brownstein MJ, Jonnalagada S, Chernova T, Dehejia A, Lavedan C, Gasser T, Steinbach PJ, Wilkinson KD, Polymeropoulos MH: The ubiquitin pathway in Parkinson's disease. Nature 1998, 395:451-452.

77. Harada T, Harada C, Wang YL, Osaka H, Amanai K, Tanaka K, Takizawa S, Setsuie R, Sakurai M, Sato Y, Noda M, Wada K: Role of ubiquitin carboxy terminal hydrolase-L1 in neural cell apoptosis induced by ischemic retinal injury in vivo. Am J Pathol 2004, 164:59-64.

78. Kwon J, Mochida K, Wang YL, Sekiguchi S, Sankai T, Aoki S, Ogura A, Yoshikawa Y, Wada K: Ubiquitin C-terminal hydrolase L-1 is essential for the early apoptotic wave of germinal cells and for sperm quality control during spermatogenesis. Biol Reprod 2005, 73:29-35.

79. Hibi K, Liu Q, Beaudry GA, Madden SL, Westra WH, Wehage SL, Yang SC, Heitmiller RF, Bertelsen AH, Sidransky D, Jen J: Serial analysis of gene expression in non-small cell lung cancer. Cancer Res 1998, 58:5690-5694.

80. Hibi K, Westra WH, Borges M, Goodman S, Sidransky D, Jen J: PGP9.5 as a candidate tumor marker for non-small-cell lung cancer. Am J Pathol 1999, 155:711-715

81. Yamazaki T, Hibi K, Takase T, Tezel E, Nakayama H, Kasai Y, Ito K, Akiyama S, Nagasaka T, Nakao A: PGP9.5 as a marker for invasive colorectal cancer. Clin Cancer Res 2002, 8:192-195.

82. Tezel E, Hibi K, Nagasaka T, Nakao A: PGP9.5 as a prognostic factor in pancreatic cancer. Clin Cancer Res 2000, 6:4764-4767.

83. Takase T, Hibi K, Yamazaki T, Nakayama H, Taguchi M, Kasai Y, Ito K, Akiyama S, Nagasaka T, Nakao A: PGP9.5 overexpression in esophageal squamous cell carcinoma. Hepatogastroenterology 2003, 50:1278-1280.

84. Yanagisawa TY, Sasahara Y, Fujie H, Ohashi Y, Minegishi M, Itano M, Morita S, Tsuchiya S, Hayashi Y, Ohi R, Konno T: Detection of the PGP9.5 and tyrosine hydroxylase mRNAs for minimal residual neuroblastoma cells in bone marrow and peripheral blood. Tohoku J Exp Med 1998, 184:229-240.

85. Mizukami H, Shirahata A, Goto T, Sakata M, Saito M, Ishibashi K, Kigawa G, Nemoto H, Sanada Y, Hibi K: PGP9.5 methylation as a marker for metastatic colorectal cancer. Anticancer Res 2008, 28:2697-2700.

86. Akishima-Fukasawa Y, Ino Y, Nakanishi Y, Miura A, Moriya Y, Kondo T, Kanai Y, Hirohashi S: Significance of PGP9.5 expression in cancer-associated fibroblasts for prognosis of colorectal carcinoma. Am J Clin Pathol 2010, 134:71-79.

87. Costello JF, Fruhwald MC, Smiraglia DJ, Rush $\sqcup$, Robertson GP, Gao X, Wright FA, Feramisco JD, Peltomaki P, Lang JC, Schuller DE, Yu L, Bloomfield CD, Caligiuri MA, Yates A, Nishikawa R, Su Huang H, Petrelli NJ, Zhang X, O'Dorisio MS, Held WA, Cavenee WK, Plass C: Aberrant CpG-island methylation has non-random and tumour-type-specific patterns. Nat Genet 2000, 24:132-138.
88. Hirata K, Ajiki T, Okazaki T, Horiuchi H, Fujita T, Kuroda Y: Frequent occurrence of abnormal E-cadherin/beta-catenin protein expression in advanced gallbladder cancers and its association with decreased apoptosis. Oncology 2006, 71:102-110.

89. Ahrendt SA, Eisenberger CF, Yip L, Rashid A, Chow JT, Pitt HA, Sidransky D: Chromosome 9p21 loss and p16 inactivation in primary sclerosing cholangitis-associated cholangiocarcinoma. J Surg Res 1999, 84:88-93.

90. Priya TP, Kapoor VK, Krishnani N, Agrawal V, Agrawal S: Role of E-cadherin gene in gall bladder cancer and its precursor lesions. Virchows Arch 2010, 456:507-514.

91. Tischoff I, Wittekind C, Tannapfel A: Role of epigenetic alterations in cholangiocarcinoma. J Hepatobiliary Pancreat Surg 2006, 13:274-279.

92. Lee S, Kim WH, Jung HY, Yang MH, Kang GH: Aberrant CpG island methylation of multiple genes in intrahepatic cholangiocarcinoma. Am J Pathol 2002, 161:1015-1022.

93. Kim BH, Cho NY, Choi M, Lee S, Jang JJ, Kang GH: Methylation profiles of multiple $\mathrm{CpG}$ island loci in extrahepatic cholangiocarcinoma versus those of intrahepatic cholangiocarcinomas. Arch Pathol Lab Med 2007, 131:923-930.

94. Yanagawa N, Tamura G, Oizumi H, Takahashi N, Shimazaki Y, Motoyama T: Frequent epigenetic silencing of the $\mathrm{p} 16$ gene in non-small cell lung cancers of tobacco smokers. Jpn J Cancer Res 2002, 93:1107-1113.

95. Chan AO, Lam SK, Wong BC, Wong WM, Yuen MF, Yeung YH, Hui WM, Rashid A, Kwong YL: Promoter methylation of E-cadherin gene in gastric mucosa associated with Helicobacter pylori infection and in gastric cancer. Gut 2003, 52:502-506.

96. Sepulveda AR, Jones D, Ogino S, Samowitz W, Gulley ML, Edwards R, Levenson V, Pratt VM, Yang B, Nafa K, Yan L, Vitazka P: CpG methylation analysis-current status of clinical assays and potential applications in molecular diagnostics: a report of the Association for Molecular Pathology. J Mol Diagn 2009, 11:266-278.

97. Tokumaru Y, Yamashita K, Kim MS, Park HL, Osada M, Mori M, Sidransky D: The role of PGP9.5 as a tumor suppressor gene in human cancer. Int J Cancer 2008, 123:753-759.

98. Okochi-Takada E, Nakazawa K, Wakabayashi M, Mori A, Ichimura S, Yasugi T, Ushijima T: Silencing of the UCHL1 gene in human colorectal and ovarian cancers. Int J Cancer 2006, 119:1338-1344.

99. Ministerio de Salud de Chile [http//www.minsal.cl]

100. Sceusi EL, Loose DS, Wray CJ: Clinical implications of DNA methylation in hepatocellular carcinoma. HPB (Oxford) 2011, 13:369-376.

101. Ghoshal K, Bai S: DNA methyltransferases as targets for cancer therapy. Drugs Today (Barc) 2007, 43:395-422.

102. Sigalotti L, Fratta E, Coral S, Cortini E, Covre A, Nicolay HJ, Anzalone L, Pezzani L, Di Giacomo AM, Fonsatti E, Colizzi F, Altomonte M, Calabrò L, Maio M: Epigenetic drugs as pleiotropic agents in cancer treatment: biomolecular aspects and clinical applications. J Cell Physiol 2007. 212:330-344.

\section{doi:10.1186/1868-7083-4-11}

Cite this article as: Letelier et al.: DNA promoter methylation as a diagnostic and therapeutic biomarker in gallbladder cancer. Clinical Epigenetics 2012 4:11

\section{Submit your next manuscript to BioMed Central and take full advantage of:}

- Convenient online submission

- Thorough peer review

- No space constraints or color figure charges

- Immediate publication on acceptance

- Inclusion in PubMed, CAS, Scopus and Google Scholar

- Research which is freely available for redistribution 